\title{
Introgression of Swertia mussotii gene into Bupleurum scorzonerifolium via somatic hybridization
}

\author{
Junfeng Wang ${ }^{1,2}$, Cuizhu Zhao ${ }^{1}$, Chang Liu', Guangmin Xia ${ }^{1 *}$ and Fengning Xiang ${ }^{1 *}$
}

\begin{abstract}
Background: The wild herb Swertia mussotii is a source of the anti-hepatitis compounds swertiamarin, mangiferin and gentiopicroside. Its over-exploitation has raised the priority of producing these compounds heterologously. Somatic hybridization represents a novel approach for introgressing Swertia mussotii genes into a less endangered species.

Results: Protoplasts derived from calli of Bupleurum scorzonerifolium and S. mussotii were fused to produce 194 putative hybrid cell lines, of which three (all derived from fusions where the S. mussotii protoplasts were pretreated for $30 \mathrm{~s}$ with UV light) later differentiated into green plants. The hybridity of the calli was confirmed by a combination of isozyme, RAPD and chromosomal analysis. The hybrid calli genomes were predominantly $B$. scorzonerifolium. GISH analysis of mitotic chromosomes confirmed that the irradiation of donor protoplasts increased the frequency of chromosome elimination and fragmentation. RFLP analysis of organellar DNA revealed that mitochondrial and chloroplast DNA of both parents coexisted and recombined in some hybrid cell lines. Some of the hybrid calli contained SmGIOH from donor, and produced swertiamarin, mangiferin and certain volatile compounds characteristic of S. mussotii. The expression of SmG1OH (geraniol 10-hydroxylase) was associated with the heterologous accumulation of swertiamarin.

Conclusions: Somatic hybrids between B. scorzonerifolium and S. mussotii were obtained, hybrids selected all contained introgressed nuclear and cytoplasmic DNA from S. mussotii; and some produced more mangiferin than the donor itself. The introgression of $\mathrm{SmGlOH}$ was necessary for the accumulation of swertiamarin.
\end{abstract}

\section{Background}

Somatic hybridization provides a means to bypass the problem of sexual incompatibility which prevents the production of many wide hybrids in the plant kingdom. The technique has been successfully demonstrated in a number of intra- and inter-specific, intergeneric, intertribal and even inter-familial combinations [1-4]. The possibility of introgression from exotic sources is of interest not just in the applied field, but also because it provides opportunities for the discovery of novel synthetic pathways for secondary metabolites and signalling compounds.

\footnotetext{
* Correspondence: xiagm@sdu.edu.cn; xfn0990@sdu.edu.cn

${ }^{1}$ The Key Laboratory of Plant Cell Engineering and Germplasm Innovation, Ministry of Education, School of Life Sciences, Shandong University, Shanda Nanlu 27\#, Jinan 250100, China

Full list of author information is available at the end of the article
}

The medicinal herb Swertia mussotii Franch is native to Tibet, where it has enjoyed a long history of use as a curative for hepatitis [5,6]. Its major active compounds have been shown to be swertiamarin, mangiferin and gentiopicroside [7]. The economic value of the species is such that there is now a real risk of species extinction as a result of over-exploitation. Swertiamarin and gentiopicroside are both iridoid monoterpenoids, but their synthetic pathway has not as yet been characterized in any detail $[8,9]$. However, many of the reactions in this pathway are known to be catalyzed by $\mathrm{P} 450$ proteins $[10,11]$. Members of this highly diverse protein family are involved in the synthesis of pigments, antioxidants and defense compounds [12], and one of particular importance for the synthesis of swertiamarin is the enzyme geraniol 10-hydroxylase (G10H) [13]. Recently, we isolated a full length cDNA clone of S. mussotii
C Biomed Central

() 2011 Wang et al; licensee BioMed Central Ltd. This is an Open Access article distributed under the terms of the Creative Commons Attribution License (http://creativecommons.org/licenses/by/2.0), which permits unrestricted use, distribution, and reproduction in any medium, provided the original work is properly cited. 
G10H (SmG10H), which has the catalytic activity of hydroxylating geraniol [14].

Bupleurum scorzonerifolium Willd $(2 \mathrm{n}=12)$, as a member of the Umbelliferae family, also is a very useful herb in Chinese traditional medicine, where it is used to treat acesodyne, diminish inflammation, ease fever and increase resistance to hepatic injury and promote immunity [15]. We previously reported plant regeneration from cultured B. scorzonerifolium protoplasts [16]. And these cultured cell lines with the fast-growing capacities have remained viable for at least 16 years, showing a chromosome numbers of $2 \mathrm{n}=12$ in over $90 \%$ of cells [3].

Our aim was to obtain somatic hybrids between $S$. mussotii and B. scorzonerifolium. The latter was chosen as the other biparent because it had a rapid growth and similar many secondary metabolic pathways $[15,16]$. We have used a number of fingerprinting methods to characterize the introgression events achieved by applying this process, and in particular have focussed on the presence of $S m G 10 H$. Finally we sought to establish the relationship between the accumulation of swertiamarin and gentiopicroside and the level of expression of $\mathrm{SmG1OH}$.

\section{Results}

\section{Growth and development of somatic fusion nuclei}

Granular calli were formed from combinations A-D after about two months of culture in liquid P5 medium in the dark, but no callus was observed in combination E. Once the clones had reached a diameter of 1.5-2 mm (Figure 1A), they were transferred to the proliferation medium $\mathrm{MB}_{2}$ (Figure 1B), where they were maintained through three rounds of sub-culturing before their final transfer to the differentiation medium $\mathrm{MB}_{3}$. A population of 194 clones was obtained by this process (Table 1 ); of these only three, all from combination B, were successfully regenerated into plants. These all developed narrow and long leaves, resembling those of B. scorzonerifolium (Figure 1C-E).

\section{Genetic characterization of the somatic hybrid calli}

Esterase isozyme analysis of 194 clones indicated that 104 had the partial characteristic band(s) of both parents and novel bands and were verifiable as hybrid (Additional file 1). A set of 88 RAPD primers was applied to generate DNA fingerprints of the presumptive hybrid calli (Additional file 2). Fragments from both biparents, as well as fragments not present in either of them, were observed in all of the hybrid clones tested (Figure 2). As $91 \%$ of the fragments in the hybrids were derived from the B. scorzonerifolium biparent, and only $0.2-2.4 \%$ from the $S$. mussotii biparent, the hybrid genomes were dominated by the recipient species (Table 2). The construction of donor nuclear genome DNAs in

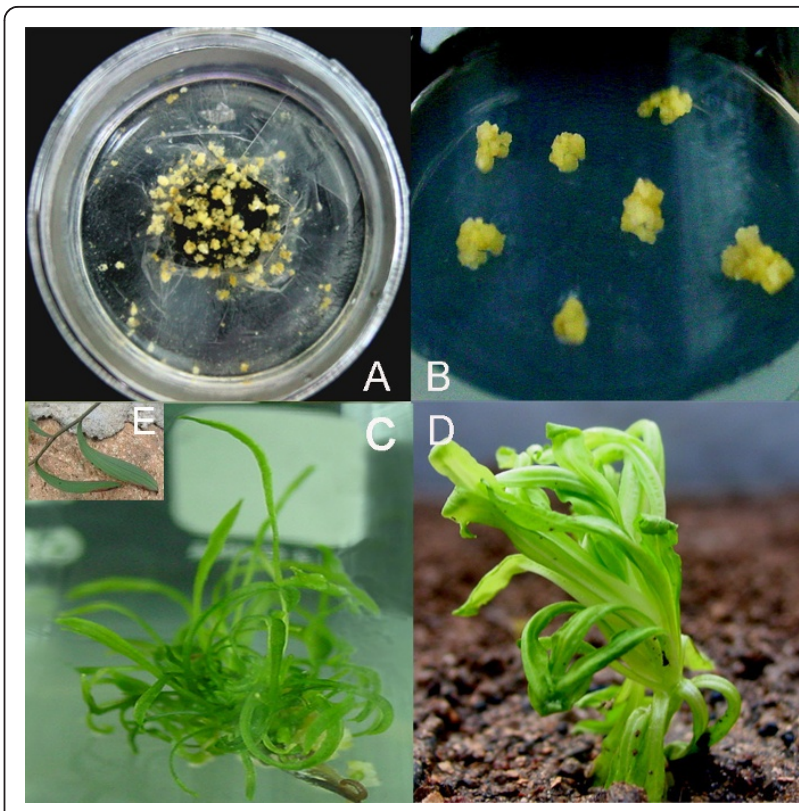

Figure 1 Somatic hybridization between $B$. scorzonerifolium and S. mussotii. A, Calli developing 30 days after somatic

hybridization; B, 60 days after somatic hybridization; C, Regenerated plant; D, S. mussotii plant; E, leaves of B. scorzonerifolium.

these hybrids were similar except hybrid C10 (Additional file 3). RAPD analysis showed in hybrids exposure of UV for $30 \mathrm{~s}$, there were $1.7 \%$ donor characteristic bands and $1.2 \%$ new bands ( $2.9 \%$ in total), however the numbers were raised to $4.5 \%$ and $3.2 \%$ (7.7\% in total) in hybrids exposure of UV for $1 \mathrm{~min}$ (Additional file 3).

\section{Karyotypes of somatic hybrid clones}

The chromosome numbers of B. scorzonerifolium and $S$. mussotii calli were 11-12 and 17-20, respectively (Figure $3 \mathrm{~A}, \mathrm{~B}$ and Table 3). In the clones derived from combination $\mathrm{A}$, the number was no lower than 15 , with most carrying 17-20 (Table 3). Combination B clones carried 11-16 chromosomes, and combination $C$ ones carried 11-14 (Table 3). Combination D clones had 11-14 (Table 3). When analysed using GISH, the biparental genomes were readily distinguishable from one another (Figure 4A, B). The three regenerable hybrid clones had chimera cells with different chromosome numbers, carrying 11-13 intact $B$. scorzonerifolium, none intact $S$. mussotii, and 1-3 recombined chromosomes (Figure 4C). In contrast, the non-regenerable clones carried 1113 intact B. scorzonerifolium, none intact S. mussotii and 5-9 recombined chromosomes (Figure 4D).

\section{Analysis of the cytoplasmic genomes of somatic hybrids} The RFLP profiles of mitochondrial DNA obtained using restriction enzymes HindIII and hybridized with probes coxI revealed that all of the cell lines analyzed contained 
Table 1 Morphology of the biparental and hybrid calli

\begin{tabular}{ccccc}
\hline Combinations & Calli regeneration & Calli growth & Plant differentiation & Plant regeneration \\
\hline A (UV0 s) & 42 clones & fast growing & 5 clones with further regeneration of shoots or roots & - \\
B (UV30 s) & 82 clones & fast growing & 14 clones with further regeneration of shoots or roots & Green plant from 3 clones \\
C (UV1 min) & 66 clones & fast growing & 7 clones with further regeneration of shoots or roots & - \\
D (UV2 $\mathrm{min})$ & 4 clones & fast growing & None & - \\
E (UV3 $\mathrm{min})$ & - & - & & - \\
\hline
\end{tabular}

B. scorzonerifolium sequences and cell lines B9 and C10 had donor bands and novel bands (Figure 5A). The chloroplast type of the hybrid cell lines was determined using rbcL as a hybridization probe. Hybridizations of HindIII digests with rbcL show that all of the cell lines analyzed contained B. scorzonerifolium fragments and 1-2 novel fragments, and cell lines B9 and B24 contained S. mussotii fragments (Figure 5B). Thus, some recombination within the mitochondrial and chloroplast genome of both parents also occurred in some hybrids.

\section{Content of medicinally active compounds}

The HPLC-based analysis of 74 of the hybrid clones determined that none accumulated gentiopicroside (Figure 6). Clones B24, B27, B132, C18, C26, C47 and C124 contained 7.4-81.2 $\mu \mathrm{g} / \mathrm{g}$ swertiamarin, while clones B6, B40, B56, C10 and C121 contained 86.3-816.8 $\mu \mathrm{g} / \mathrm{g}$ mangiferin. Notably, the mangiferin content of clones B6, B56 and C10 was higher than that of the callus derived from the $S$. mussotii biparent (Table 4).

\section{Volatile compounds in the biparent and hybrid clones}

The volatile compound content of the hybrid clones, as assessed by GC-MS, largely resembled that of the B. scorzonerifolium biparent (Additional file 4). Nevertheless, a
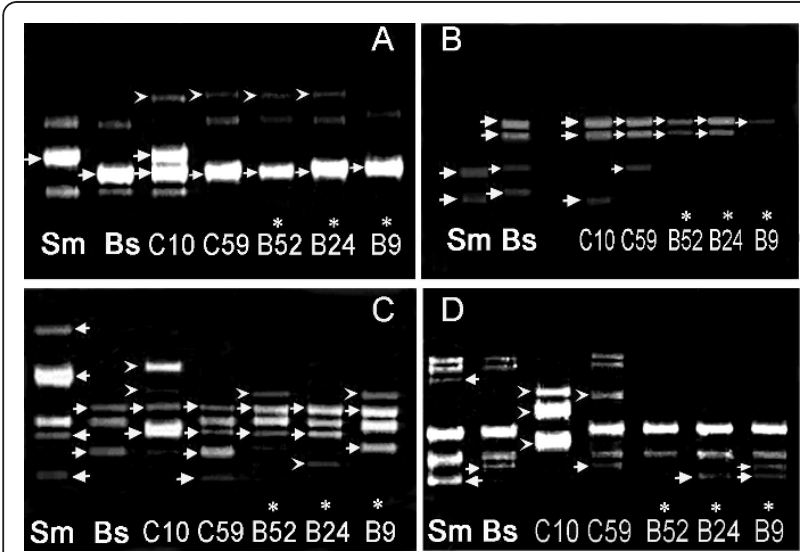

Figure 2 RAPD analysis of hybrid clones. A, Primer H19; B, Primer Q15; C, Primer Q8; D, Primer N20. Sm, S. mussotii; Bs, B. scorzonerifolium. Lanes 2, 3, 10, 13 and 14 refer, respectively to hybrid clones B9, B24, B52, C59 and C10. $\rightarrow$, Distinctive bands inherited from the donor or recipient. $\bullet$, Bands not present in either the donor or the recipient. ${ }^{*}$, The regenerated hybrid clones. few donor compounds, in particular coumaron and linoleic acid, were detectable in some of the hybrid clones, along with a small number of compounds (e.g., cyclohexanol and dodecanoyl) which were not detected in either biparent (Table 5).

\section{The introgression of $\mathbf{P} 450$ genes}

Degenerate PCR analysis was used to detect the P450 genes in clones A6, A67, B24, B27, B132, C18, C26, C47 and $\mathrm{C} 124$, with various contents of swertiamarin and mangiferin (Figure 7 and Additional file 5). Only amplicon of primer CYP76 was distinguished among the bipatents and hybrid A6 (Figure 7). Each cDNA template amplified a single fragment in the size range 1100 1500 bp in hybrids above and the bipatents using primer CYP76. Sequencing identified 11 distinct fragments. An analysis of the set of polypeptides predicted from these nucleotide sequences identified their homology to the $\mathrm{G} 10 \mathrm{H}$ gene of Catharanthus roseus (geraniol 10-hydroxylase gene, GenBank accession number AJ251269). A full length $S m G 10 H$ sequence of 1488 bp (Genebank accession GU168041) was obtained from $S$. mussotii. The $\mathrm{G} 10 H$ sequences present in clones B24, B27, B132, C18, C26, C47 and C124 were identical to that of $\mathrm{SmG10H}$ (Additional file 6). In two clones (A6 and A67), the G10H sequence shared 53.1\% homology with $\mathrm{SmG10H}$ (Additional file 7).

\section{Up-regulation of SmG10H is correlated with the accumulation of swertiamarin}

Semi-quantitative RT-PCR suggested that the expression SmG1OH varied among the clones (S. mussotii > B24 > B132 > C47 > A6, see Figure 8 and Table 4). The swertiamarin content of $S$. mussotii $(933 \mu \mathrm{g} / \mathrm{g})$ was substantially higher than that in the hybrid clones $(0-81.2 \mu \mathrm{g} / \mathrm{g})$, while clones B24 and B132 produced more than clone C47; neither swertiamarin nor $S m G 10 H$ expression were detected in clone A6. These results suggest that up-regulation of $\mathrm{SmG} 10 \mathrm{H}$ is correlated with the accumulation of swertiamarin.

\section{Discussion}

Hybrid clones experience both chromosome elimination and introgression

Across a range of hybrid combinations, the regeneration of viable plants has proven to be the main bottleneck in 
Table 2 Frequency of donor and recipient RAPD DNA fragments among hybrid calli and regenerated plants

\begin{tabular}{|c|c|c|c|c|c|}
\hline \multirow[t]{2}{*}{ 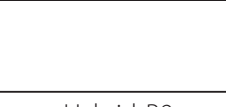 } & \multirow[t]{2}{*}{ Total bands } & \multicolumn{2}{|c|}{ Characteristic bands } & \multicolumn{2}{|c|}{ Frequency (\%) } \\
\hline & & Acceptor bands & Donor bands & Acceptor bands/Total bands & Donor bands/Total bands \\
\hline Hybrid B9 & 538 & 524 & 3 & 96.68 & 0.60 \\
\hline Hybrid B24 & 527 & 523 & 1 & 97.48 & 0.20 \\
\hline Hybrid B52 & 526 & 517 & 4 & 96.46 & 0.81 \\
\hline Hybrid C59 & 528 & 521 & 2 & 97.02 & 0.41 \\
\hline Hybrid C10 & 539 & 498 & 12 & 91.80 & 2.41 \\
\hline B. scorzonerifolium & 546 & - & - & - & - \\
\hline S. mussotii & 456 & - & - & - & - \\
\hline Average & & $516.6( \pm 10.7)$ & $4.4( \pm 4.4)$ & $95.9( \pm 2.3)$ & $0.9( \pm 0.9)$ \\
\hline
\end{tabular}

the somatic hybridization process [1,3,4]. Much of the problem appears to be related to the hybrid incompatibility of the biparents. This hybrid incompatibility can be alleviated if sufficient of the donor biparent's chromosomes are either completely eliminated, or at least are broken down so that sub-chromosomal segments become fused with the recipient biparent's chromosome $[2,17,18]$. The somatic chromosome number of successful regenerants has been shown to be close to or just slightly lower than that of the recipient biparent $[19,20]$. Here, only three of the population of the 194 somatic $B$. scorzonerifolium / S. mussotii fusion nuclei proved to be regenerable. Both the genetic and cytological analyses showed that the constitution of the regenerable hybrid calli was close to that of the recipient parent B. scorzonerifolium, which suggested that large-scale chromosome elimination is necessary to restore the somatic hybrids' ability to regenerate.

UV irradiation of the donor biparent's protoplasts prior to fusion has been shown to encourage chromosomal

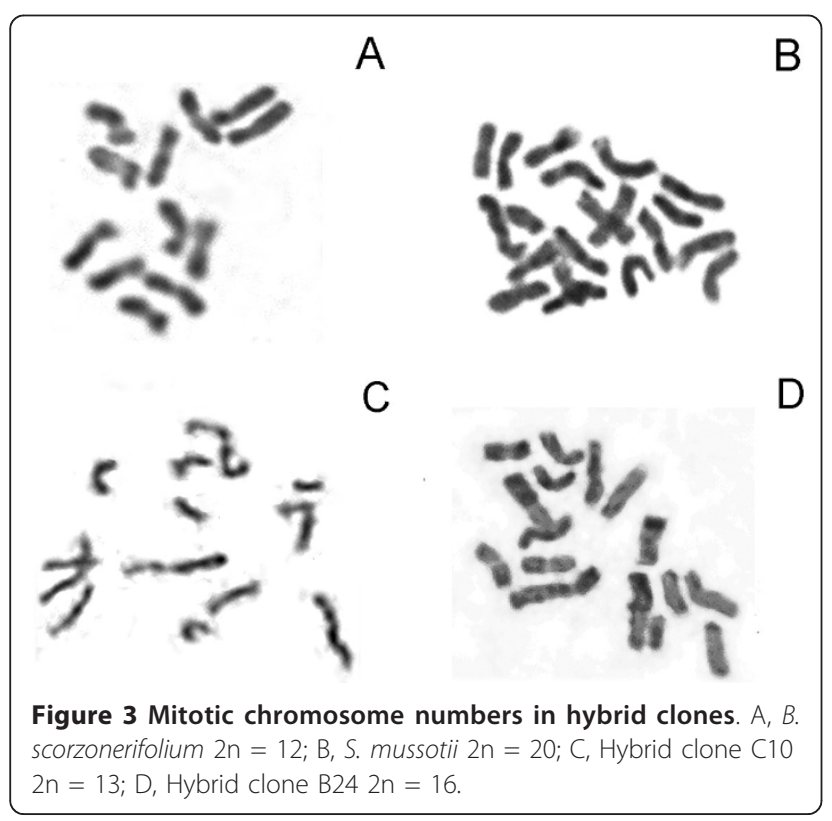

elimination [21-23]. The hybrid cell lines B24 and C10 both retained 11-13 B. scorzonerifolium chromosomes, none entire $S$. mussotii, but the former retained 1-3 introgression chromosomes, while the latter retained more (5-9) introgression chromosomes (Figure 4). This result is consistent with the pattern whereby raising the UV dosage decreases the number of intact donor chromosomes but increases the frequency of donor introgression [20,23].

\section{Characteristics of the hybrid cytoplasmic genome}

Earlier investigations showed that recombination and (or) coexistence mitochondria DNA from both parents is common in somatic hybrids [23]. In contrast, chloroplast DNA often had random and equal segregation $[24,25]$. Mixed populations and recombination of chloroplast DNA have only rarely been detected [26]. In our previous studies, mixed and recombined mitochondrial DNA was also seen in wheat somatic hybrids $[23,27,28]$. In this study, the mitochondrial and chloroplast DNA of both parents also coexisted in most hybrid cell lines. Novel DNA segments appeared in some hybrids, which

Table 3 Variation for somatic chromosome number in biparental and hybrid calli

\begin{tabular}{|c|c|c|c|c|c|c|}
\hline & \multirow{2}{*}{$\begin{array}{l}\text { Number of cell } \\
\text { samples }\end{array}$} & \multicolumn{5}{|c|}{ Numeber of chromosomes } \\
\hline & & $\begin{array}{l}11- \\
12\end{array}$ & $\begin{array}{l}13- \\
14\end{array}$ & $\begin{array}{l}15- \\
16\end{array}$ & $\begin{array}{l}17- \\
18\end{array}$ & $\begin{array}{l}19- \\
20\end{array}$ \\
\hline $\begin{array}{c}\text { B. } \\
\text { scorzonerifolium }\end{array}$ & 33 & 33 & - & - & - & - \\
\hline S. mussotii & 42 & - & - & - & 7 & 35 \\
\hline Hybrid A10 & 37 & - & - & 7 & 25 & 5 \\
\hline Hybrid A22 & 36 & - & - & 4 & 23 & 9 \\
\hline Hybrid A24 & 61 & - & - & 12 & 41 & 8 \\
\hline Hybrid B9 & 59 & - & 7 & 39 & 13 & - \\
\hline Hybrid B24 & 63 & - & 41 & 10 & 12 & - \\
\hline Hybrid B52 & 49 & - & 5 & 36 & 8 & - \\
\hline Hybrid C10 & 51 & 13 & 38 & - & - & - \\
\hline Hybrid C64 & 44 & 12 & 32 & - & - & - \\
\hline Hybrid C88 & 62 & 22 & 40 & - & - & - \\
\hline Hybrid D2 & 34 & 23 & 11 & - & - & - \\
\hline
\end{tabular}




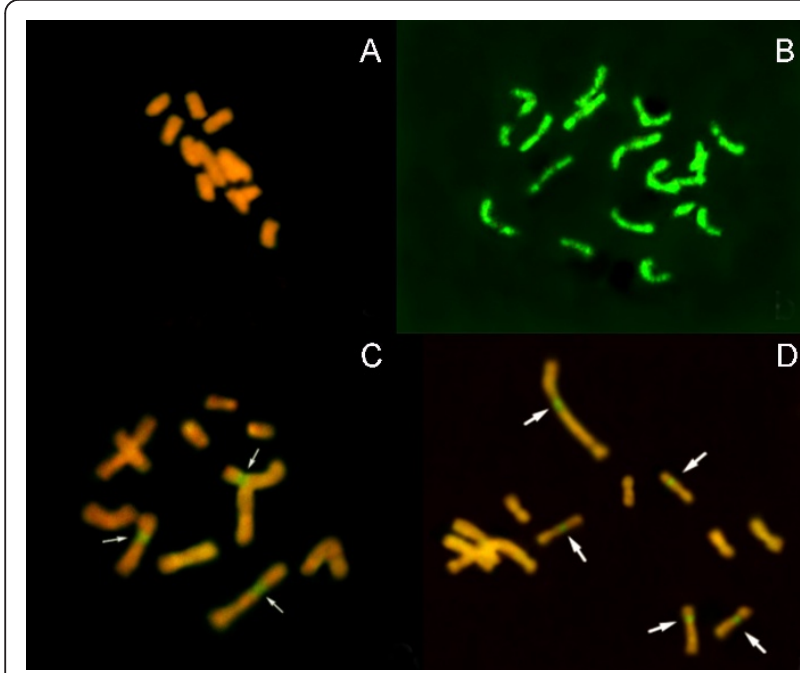

Figure $4 \mathrm{GISH}$ analysis of mitotic chromosomes in hybrid clones. A, B. scorzonerifolium; B, S. mussotii; C, Hybrid clone B24; D, Hybrid clone C10. $\rightarrow$, Presence of donor chromosome segment.

may have been the result of recombination of mitochondria and chloroplast DNA (Figure 5). We conclude that in the inter-familial hybridization between $B$. scorzonerifolium and $S$. mussotii, it is possible to transfer donor mitochondrial and chloroplast genes.

\section{The engineering of medicinally active compounds}

Somatic hybrids could increase the content of the efficacious compounds from traditional Chinese medicinal

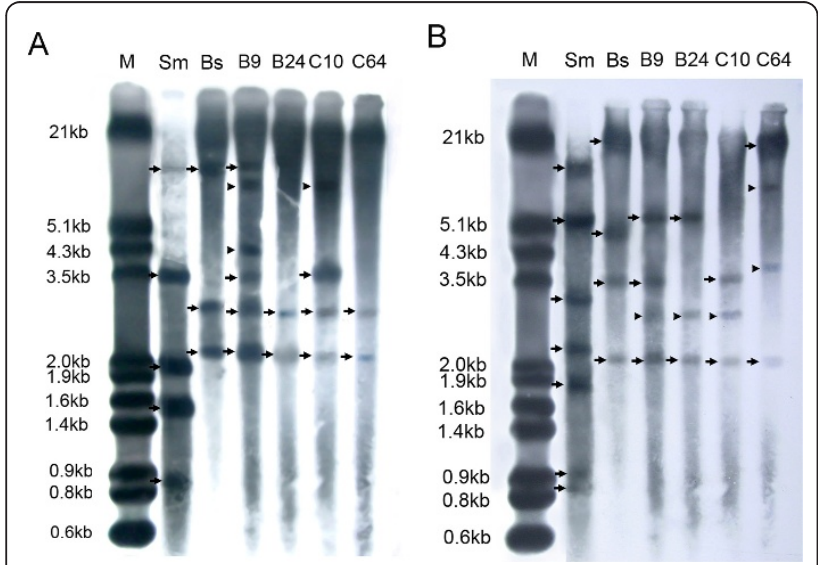

Figure 5 RFLP of profiles of mitochondrial and chloroplast DNA of S. mussotii, $B$. scorzonerifolium, and the hybrid cell lines from combinations $B$ and $C$ between $S$. mussotii and $B$. scorzonerifolium. M, labeled $\lambda \mathrm{DNA}$ digested by Hindlll+EcoRl; Bs, $B$. scorzonerifolium; Sm, S. mussotii; B9, B24, C10 and C64, hybrid cell lines of S. mussotii -B. scorzonerifolium. Arrows indicate bands of the S. mussotii and B. scorzonerifolium; arrowheads indicate new bands. A, Hindlll-digested genomic DNA probed with the mitochondrialspecific probes coxl. B, Hindlll-digested genomic DNA probed with the chloroplast-specific probe rbcL. materials. However, only a few cases succeeded [29]. The content of swertiamarin, mangiferin and gentiopicroside varied markedly among the hybrid clones (Table 4). With respect to swertiamarin, no clone accumulated close to the level which was achieved by the donor calli (Figure 6). However, with respect to mangiferin, five

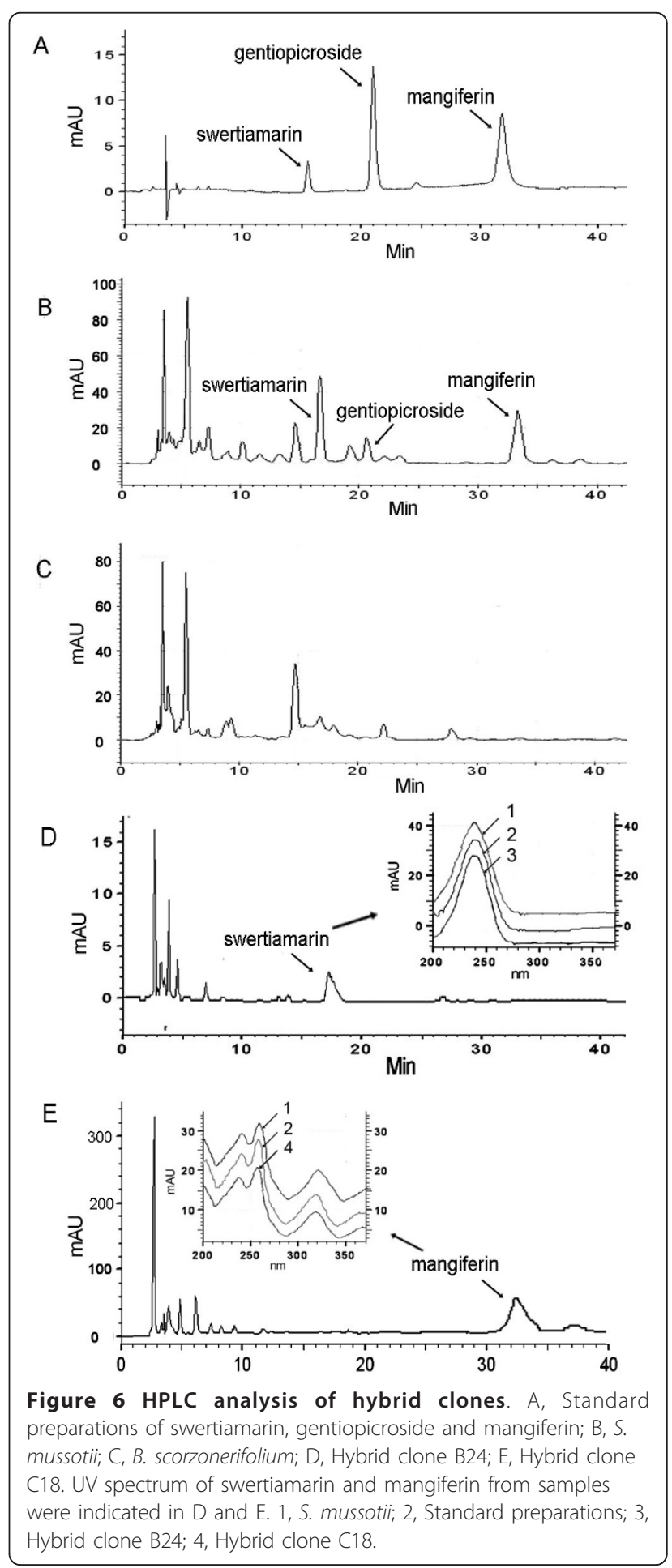


Table 4 Content of medicinally active compounds in biparental and hybrid calli

\begin{tabular}{|c|c|c|c|c|c|c|}
\hline & \multicolumn{2}{|c|}{ Swertiamarin } & \multicolumn{2}{|c|}{ Gentiopicroside. } & \multicolumn{2}{|c|}{ Mangiferin } \\
\hline & Retention time (min) & Content $(\mathrm{mg} / \mathrm{g})$ & Retention time (min) & Content $(\mathrm{mg} / \mathrm{g})$ & Retention time (min) & Content $(\mathrm{mg} / \mathrm{g})$ \\
\hline S. mussotii & $16.93 \pm 0.10$ & $0.9298 \pm 0.0039$ & $20.65 \pm 0.17$ & $0.4235 \pm 0.0026$ & $33.51 \pm 0.14$ & $0.6641 \pm 0.0027$ \\
\hline B. scorzonerifolium & - & - & - & - & - & - \\
\hline Hybrid A6 & - & - & - & - & - & - \\
\hline Hybrid A67 & - & - & - & - & - & - \\
\hline Hybrid B6 & - & - & - & - & $31.75 \pm 0.15$ & $0.7970 \pm 0.0034$ \\
\hline Hybrid B24 & $17.55 \pm 0.15$ & $0.0812 \pm 0.0022$ & - & - & - & - \\
\hline Hybrid B27 & $17.05 \pm 0.14$ & $0.0769 \pm 0.0026$ & - & - & - & - \\
\hline Hybrid B40 & - & - & - & - & $31.37 \pm 0.16$ & $0.0996 \pm 0.0033$ \\
\hline Hybrid B56 & - & - & - & - & $31.79 \pm 0.12$ & $0.7903 \pm 0.0029$ \\
\hline Hybrid B132 & $16.43 \pm 0.16$ & $0.0746 \pm 0.0023$ & - & - & - & - \\
\hline Hybrid C10 & - & - & - & - & $32.24 \pm 0.13$ & $0.8168 \pm 0.0037$ \\
\hline Hybrid C18 & $16.87 \pm 0.12$ & $0.0083 \pm 0.0015$ & - & - & - & - \\
\hline Hybrid C26 & $16.68 \pm 0.13$ & $0.0082 \pm 0.0012$ & - & - & - & - \\
\hline Hybrid C47 & $16.29 \pm 0.14$ & $0.0102 \pm 0.0017$ & - & - & - & - \\
\hline Hybrid C121 & - & - & - & - & $32.08 \pm 0.14$ & $0.0863 \pm 0.0034$ \\
\hline Hybrid C124 & $17.21 \pm 0.18$ & $0.0074 \pm 0.0016$ & - & - & - & - \\
\hline
\end{tabular}

clones (B6, B40, B56, C10 and C121) outperformed the donor, two accumulated markedly less (B40 and C121), and two (A6 and B24) produced no detectable level (Table 4). The accumulation by the hybrid clones of a number of volatiles associated with the donor species is also indicative of the transfer of whole synthetic pathways from $S$. mussotii to a genotype which is largely $B$. scorzonerifolium.

The clones best able to accumulate mangiferin tended to have retained the most introgressed chromosomes

Table 5 Partial special volatile compounds in hybrids compared with the parents

\begin{tabular}{|c|c|c|c|c|c|c|}
\hline Sample & Compound & Molecular formula & S. mussotii & Hybrid A6 & Hybrid B24 & B. scorzonerifolium \\
\hline 1 & 2-pyrrolidone & $\mathrm{C}_{4} \mathrm{H}_{7} \mathrm{NO}$ & - & - & + & + \\
\hline 2 & dihydropyran & $\mathrm{C}_{5} \mathrm{H}_{8} \mathrm{O}$ & + & - & + & - \\
\hline 3 & 2,3-dimethyl pyrazine & $\mathrm{C}_{6} \mathrm{H}_{8} \mathrm{~N}_{2}$ & + & - & + & - \\
\hline 4 & cyclohexanol & $\mathrm{C}_{6} \mathrm{H}_{12} \mathrm{O}$ & - & + & + & - \\
\hline 5 & 2,4-dihydroxy-2,5-dimethyl-3(2H)-furanone & $\mathrm{C}_{6} \mathrm{H}_{8} \mathrm{O}_{4}$ & + & + & - & - \\
\hline 6 & 2,5- methenyl furfuran & $\mathrm{C}_{6} \mathrm{H}_{3} \mathrm{O}_{3}$ & - & + & + & - \\
\hline 7 & 2,5-dimethyl-4-hydroxy-3(2H)-furanone & $\mathrm{C}_{6} \mathrm{H}_{8} \mathrm{O}_{3}$ & - & + & - & - \\
\hline 8 & ethyl vinyl ether & $\mathrm{C}_{6} \mathrm{H}_{12} \mathrm{O}$ & - & - & + & - \\
\hline 9 & phenol & $\mathrm{C}_{6} \mathrm{H}_{6} \mathrm{O}$ & + & + & + & - \\
\hline 10 & heptylic acid & $\mathrm{C}_{7} \mathrm{H}_{14} \mathrm{O}_{2}$ & + & - & + & - \\
\hline 11 & diethyl cyclopentane & $\mathrm{C}_{7} \mathrm{H}_{20}$ & - & + & + & + \\
\hline 12 & 1-(3-aminopropoxy)-2-ethoxyethane & $\mathrm{C}_{7} \mathrm{H}_{17} \mathrm{NO}_{2}$ & + & - & + & - \\
\hline 13 & salicylic acid & $\mathrm{C}_{7} \mathrm{H}_{6} \mathrm{O}_{3}$ & + & + & + & - \\
\hline 14 & hyacinthin & $\mathrm{C}_{8} \mathrm{H}_{8} \mathrm{O}$ & - & - & + & + \\
\hline 15 & 2,5-dimethyl-4-hydroxy-3-furanone & $\mathrm{C}_{8} \mathrm{H}_{14} \mathrm{O}_{3}$ & - & + & - & + \\
\hline 16 & benzendicarboxylic acid & $\mathrm{C}_{8} \mathrm{H}_{6} \mathrm{O}_{4}$ & + & - & + & - \\
\hline 17 & coumaron & $\mathrm{C}_{8} \mathrm{H}_{8} \mathrm{O}$ & + & - & + & - \\
\hline 18 & methylnaphthalene & $\mathrm{C}_{11} \mathrm{H}_{10}$ & - & - & + & + \\
\hline 19 & dodecanoyl & $\mathrm{C}_{12} \mathrm{H}_{24} \mathrm{O}$ & - & + & + & - \\
\hline 20 & tetradecanoic acid & $\mathrm{C}_{14} \mathrm{H}_{28} \mathrm{O}_{2}$ & - & + & - & + \\
\hline 21 & tetradecanol & $\mathrm{C}_{14} \mathrm{H}_{28} \mathrm{O}$ & + & - & + & + \\
\hline 22 & 1-hydroxy-3,7,8-trimethoxyxanthenone & $\mathrm{C}_{16} \mathrm{H}_{14} \mathrm{O}_{6}$ & + & - & + & - \\
\hline 23 & linoleic acid & $\mathrm{C}_{18} \mathrm{H}_{32} \mathrm{O}_{2}$ & + & - & + & - \\
\hline 24 & 1,2 benzendicarboxylic acid octyl nitrite & $\mathrm{C}_{24} \mathrm{H}_{38} \mathrm{O}_{4}$ & + & + & - & - \\
\hline 25 & 2-ethylhexyl hexadecanoate & $\mathrm{C}_{24} \mathrm{H}_{48} \mathrm{O}_{2}$ & + & + & - & + \\
\hline
\end{tabular}




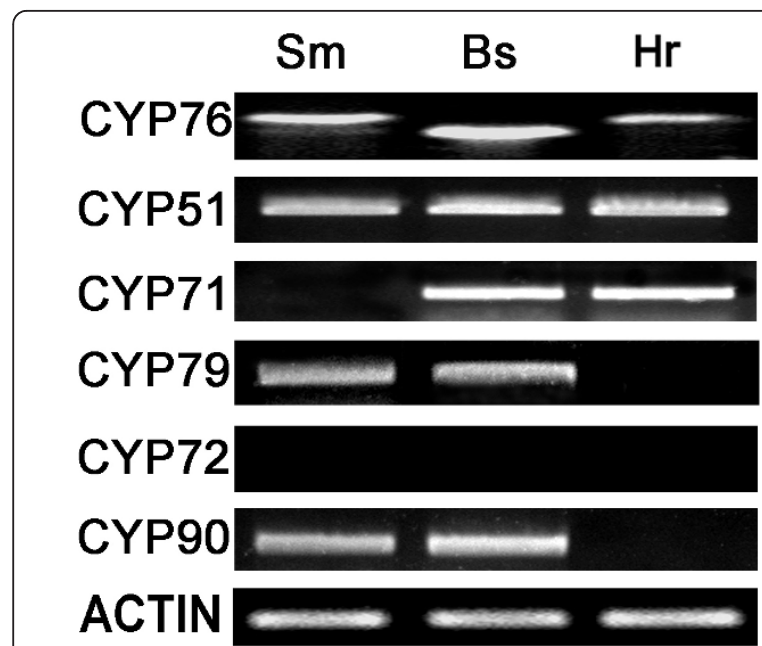

Figure 7 Allelic variation for $\mathrm{G} 10 \mathrm{H}$ in hybrid and biparent calli. $\mathrm{Sm}, \mathrm{S}$. mussotii; Bs, B. scorzonerifolium; $\mathrm{Hr}$, hybrid.

(Figure 4). Similarly the RAPD fingerprinting showed that these clones also inherited the most donor DNA (Table 2 and Figure 2). Presumably maximizing the yield of the donor's medicinally active compounds in a somatic hybrid clone requires transferring as much donor DNA as possible.

The relationship between $\mathrm{SmG1OH}$ expression and swertiamarin content

According to RT-PCR at least, the expression of $\mathrm{SmG1OH}$ varied among the hybrid clones. Nevertheless, its level was largely correlated with the accumulation of

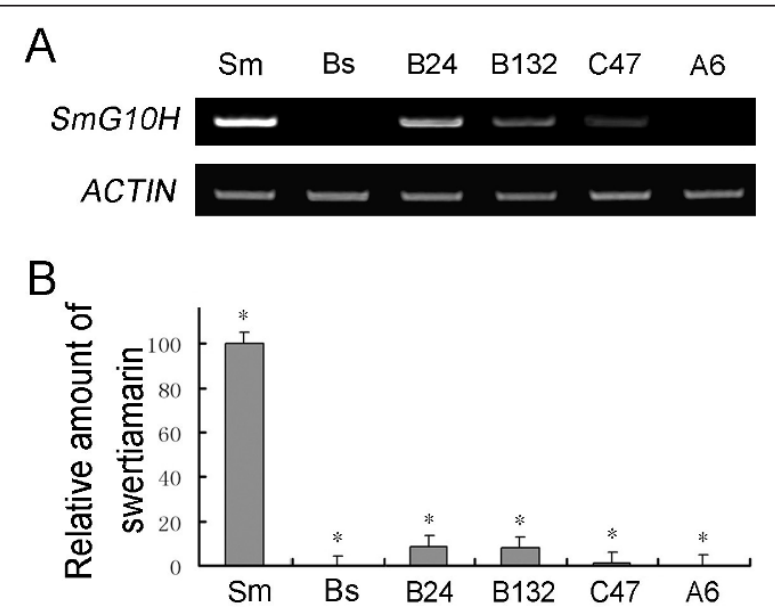

Figure 8 The expression of $\mathrm{SmG10H}$ and accumulation of swertiamarin in hybrid clones. A, Variation for level of $\mathrm{SmG1OH}$ expression. B, Swertiamarin content. Sm, S. mussotii; Bs, B. scorzonerifolium; B24 and B132, hybrid clones from combination B; C47, hybrid clone from combination C; A6, hybrid clone from combine A. Bars represent the standard error of the mean; $t$ test, * $P<0.05$. swertiamarin (Figure 8), implying that the transfer of $\mathrm{SmG1OH}$ alone cannot be expected to be sufficient to guarantee heterologous expression. The implied requirement for other genes in the synthetic pathway underlines the difficulty that a more reductive, tansgenic strategy would face in obtaining the successful production of swertiamarin in a heterologous situation. The identification of hybrid clones able to accumulate this medicinally significant compound therefore confirms the potential of somatic hybridization as a viable route for engineering the production of such molecules in plants.

\section{Conclusions}

In conclusion, somatic hybridization provides a new way to introgression secondary metabolites and related genes in phylogenetic distant species. Here we have managed to obtain somatic hybrids of B. scorzonerifolium / S . mussotii with an appreciable content of swertiamarin. The nuclear and cytoplasmic genes from donor were transferred into the genome DNA of hybrid clones. The introgression of $\mathrm{SmG1OH}$ was necessary for the accumulation of swertiamarin. Therefore, the potential of somatic hybridization is a viable route for engineering the production of such molecules in plants.

\section{Methods}

\section{Origin of biparental protoplasts}

Immature seed of Swertia mussotii Franch was collected from Yushu county, Qinghai province, China. Voucher specimens had been deposited at Qinghai Normal University. The seed was surface-sterilized by immersion first in $70 \%(\mathrm{v} / \mathrm{v})$ ethanol for $30 \mathrm{~s}$ and then in $0.1 \% \mathrm{w} / \mathrm{v}$ aqueous mercuric chloride for $10 \mathrm{~min}$. The seeds were plated on Murashige and Skoog [30] basal medium (MS) containing $1 \mathrm{mg} / \mathrm{l}$ 2, 4-dichlorophenoxyacetic acid (2, 4-D) using the method described by Xiang et al. [31] to induce the production of callus, the source of donor protoplasts. The callus was subcultured on MB medium (MS medium supplemented by B5 vitamins [23], $2 \mathrm{mg} / \mathrm{l}$ glycine, $146 \mathrm{mg} / \mathrm{l}$ glutamine, $300 \mathrm{mg} / \mathrm{l}$ casein hydrolysate, $1 \mathrm{mg} / \mathrm{l} \mathrm{2}$, 4-D, $30 \mathrm{~g} / \mathrm{l}$ sucrose and $7.5 \mathrm{~g} / \mathrm{l}$ agar at $\mathrm{pH}$ 5.8) at interval of 15 days. The recipient protoplasts were obtained from Bupleurum scorzonerifolium Willd calli induced in the same way; these have been kept in culture for 12 years under $18-20 \mu \mathrm{mol} \mathrm{m}^{-2} \mathrm{~s}^{-1}$ cool white light in MB medium. Protoplasts were isolated from all calli following established methods [32].

\section{Protoplast fusion and post fusion culture}

Preparations of both protoplast types were washed in 0.6 $\mathrm{M}$ mannitol, $5 \mathrm{mM} \mathrm{CaCl}_{2}$, then transferred to a $3.5 \mathrm{~cm}$ petridish to form a thin layer. Donor protoplasts were UV irradiated at $380 \mu \mathrm{W} / \mathrm{cm}^{2}$ for either $0 \mathrm{~s}(\mathrm{~S} 1), 30 \mathrm{~s}$ (S2), 1 min (S3), 2 min (S4) or 3 min (S5), after which 
they were mixed with the recipient protoplasts at a ratio of $1: 1$. The fusion protocol followed the PEG method described by Xia and Chen [32]. Fusion products, which combinations A-E were corresponding donor protoplasts S1-S5, were cultured on P5 medium [32]. Once calli had reached a diameter of $1.5-2.0 \mathrm{~mm}$, they were transferred to $\mathrm{MB}_{2}$ medium and sub-cultured every two weeks for 1-2 months. At this stage, the calli were removed to a $\mathrm{MB}_{3}$ solid medium (MB medium supplemented with 1 $\mathrm{mg} / \mathrm{l}$ 6-benzylaminopurine and $1 \mathrm{mg} / \mathrm{l}$ indoleacetic acid). Regenerated plantlets were transferred to a seedlingstrengthening medium [32].

\section{Callus genotying}

Esterase isozymes were extracted from calli and assayed as described elsewhere [33]. DNA was extracted from selected calli according to Doyle and Doyle [34], and used as template for RAPD reactions based on 88 decamer primers (Promega Inc., Madison, Wis.). The PCRs were conducted according to Xia et al. [35], and the amplicons were electrophoresed through $1.5 \%$ agarose gels before staining in $0.5 \mu \mathrm{g} / \mathrm{ml}$ ethidium bromide. These RAPD experiments were repeated at least 3 times and only the repeatable bands were record.

\section{Mitotic chromosome analysis}

Mitotic chromosome spreads from callus and root tip cells were prepared as described by [20]. For GISH analysis, total genomic $S$. mussotii DNA was used as the probe, and the procedure described by Xiang et al. [20] was applied.

\section{RFLP analyis}

Genomic DNA of the putative hybrid cell lines and their parents was extracted as described previously [34]. For the analysis of chloroplast (cp) and mitochondrial (mt) DNA, 15-20 $\mu$ g of total DNA was digested with HindIII and electrophoresed through $0.8-1 \%$ agarose gels in TBE buffer. The DNA was transferred onto a nylon membrane (Hybond $\mathrm{N}+$, Amersham-Phamarcia, UK) using 0.4 M NaOH. Probe labelling, hybridization, and washing were carried out with the ECL Random Labeling and detection system (Amersham-Phamarcia, UK) according to the manufacturer's instructions. Plasmids containing mtDNA fragments (coxI) from maize (Zea mays L.) and a cpDNA fragment (rbcL) from spinach (Spinacia oleracea L.) were kindly provided by Dr. G. Spangenberg (Institute for Plant Sciences, Swiss Federal Institute of Technologies, CH-8092 Zürich, Switzerland). The inserts were cut out of a gel and labelled.

\section{Semi-quantitative RT-PCR analysis}

Semi-quantitative RT-PCR was conducted on total RNA isolated from hybrid and two parents calli using the TriZOL reagent (Invitrogen, USA). First strand cDNA was synthesized using Superscript II reverse transcriptase M-MLV (TakaRa, Japan), following the manufacturer's directions. Degenerate primers targeting the gene from Arabidopsis thaliana encoding cytochrome P450 monooxygenase (Additional file 2) were applied to the cDNA templates. The amplicons derived from degenerate primers targeting the two $S$. mussotii actin genes $S m A c t 1$ and $S m A c t 2$ were used to normalize the RT-PCR signal. Each PCR comprised 19-25 cycles of $94^{\circ} \mathrm{C} / 30 \mathrm{~s}, 53^{\circ} \mathrm{C} / 30 \mathrm{~s}, 72^{\circ} \mathrm{C} / 90 \mathrm{~s}$, and was completed with a $10 \mathrm{~min}$ extension at $72^{\circ} \mathrm{C}$. Each PCR was replicated at least three times, based on independent biological samples.

\section{HPLC analysis}

The calli were shade-dried for seven days and ground to powder. After the addition of $20 \mathrm{ml}$ methanol to $1 \mathrm{~g}$ powdered callus, the resulting suspension was sonicated for $1 \mathrm{~h}$ at room temperature, then filtered through a $0.45 \mu \mathrm{m}$ membrane filter. A $10 \mu \mathrm{l}$ aliquot of filtrate was injected into a LC-10AD HPLC system (Shimadzu Co., Japan) equipped with a C18 column (Phenomenex Luna, $4.6 \times 250 \mathrm{~mm}$ i.d., $5 \mu \mathrm{m})$. The mobile phase was water: methanol (75:25), and the outflow $(0.8 \mathrm{ml} / \mathrm{min})$ was scanned at $259 \mathrm{~nm}$ [14]. Standards for swertiamarin, gentiopicroside and mangiferin were provided by the National Institute for the Control of Pharmaceutic and Biological Products (Beijing, China). All above experiments were carried out four times. In all statistical tests, values of $\mathrm{P}$ lower than 0.05 were interpreted as indicating statistically significant differences. Results were analysed with SAS statistical package (Version5.1, SAS Institute Inc., Cary, NC).

\section{Capillary gas chromatography/mass spectrometry (GC- MS) analysis}

Methanol extracts of the calli were prepared according to Liu et al. [36], and then subjected to GC/MS, using a Micromass GCT gas chromatograph-mass spectrometer (England) fitted with a DB-5 $\mathrm{ms}$ column $(0.25 \mathrm{~mm} \times 30$ $\mathrm{m}, 0.25 \mu \mathrm{m}$ film thickness) (J W Scientific, Folsom, CA), with a helium flow rate of $1 \mathrm{ml} / \mathrm{min}$, and operating at $70 \mathrm{eV}$ ionization voltage with a scan range of 20-600 $\mathrm{Da}$. The column temperature was set at $200^{\circ} \mathrm{C}$ for 2 min, then elevated to $300^{\circ} \mathrm{C}$ at $15^{\circ} \mathrm{C} / \mathrm{min}$ and held at $300^{\circ} \mathrm{C}$ for $7 \mathrm{~min}$.

\section{Additional material}

Additional file 1: Esterase analysis of calli. Sm, S. mussotii; Bs, B. scorzonerifolium. - Isozymes not present in either the donor or the recipient; $\rightarrow$, Distinctive isozymes inherited from the donor or recipient. * important calli. 
Additional file 2: RAPD analysis of biparental and hybrid calli. Sm: Fragments inherited from S. mussotii; Bs: Fragments inherited from $B$. scorzonerifolium; $\mathrm{T}$, total of the parents and new bands; $\mathrm{N}$ : fragments not present in either biparental profile.

Additional file 3: Frequency in the hybrid clones of donor fragments, and fragments absent from both biparental profiles. Additional file 4: GC-MS analysis of volatile compounds present in the biparental and hybrid calli.

Additional file 5: Sequences of primer used for these experiments

Additional file 6: Alignment of $\mathrm{G} 10 \mathrm{H}$ nucleotide sequences. Smg10 h, g10 h from S. mussotii; B24 g10 h, g10 h from hybrid B24; C26 g10 h, g10 h from hybrid C26.

Additional file 7: Alignment of $\mathrm{G} 10 \mathrm{H}$ peptide sequences. The red line indicates the conserved domain within the sequence. SmG1OH-P, G1OH from S. mussotii; B24G10H-P, G10H from hybrid B24; A6G10H-P, G10H from hybrid A6; BsG10H-P, G10H from B. scorzonerifolium.

\section{Acknowledgements}

This research was made possible by financial support from the Chinese 'National Special Science Research Program' (grant no. 2007CB948203), 'Natural Education Ministry Doctor Station Foundation Fellowship' (grant no. 913111006) and 'National Natural Science Foundation' (grants no. 30970243 and 30771116), and Excellent Youth Foundation of Shandong Province of China (grant no. JQ200810), and 'Science \&Technology Plan of Shandong Province' (grant no. 2009GG10002001). We acknowledge the linguistic help given by http://www.smartenglish.co.uk in English editing this manuscript.

\section{Author details}

'The Key Laboratory of Plant Cell Engineering and Germplasm Innovation, Ministry of Education, School of Life Sciences, Shandong University, Shanda Nanlu 27\#, Jinan 250100, China. ${ }^{2}$ Crop Germplasm Resources Centre of Shandong, Shandong Academy of Agricultural Sciences, Gongye Beilu 202\#, Jinan 250100, China.

\section{Authors' contributions}

JFW conducted most of the experiments and helped in the writing of the $\mathrm{ms}$; CZZ contributed to the GC/MS experiment and participated in the drafting of the manuscript; GMX was responsible for the design and coordination of the study; FNX conceived the study and was responsible for the final version of the ms. The final manuscript were read and approved by all authors.

Received: 18 November 2010 Accepted: 25 April 2011

Published: 25 April 2011

\section{References}

1. Dudits D, Maroy E, Praznovszky T, Olah Z, Gyorgyey J, Cella R: Transfer of resistance traits from carrot into tobacco by asymmetric somatic hybridization: regeneration of fertile plants. Proc Natl Acad Sci USA 1987, 84:8434-8438.

2. Kisaka H, Lee H, Kisaka M, Kanno A, Kang K, Kameya T: Production and analysis of asymmetric hybrid plants between monocotyledon (Oryza sativa L.) and dicotyledon (Daucus carota L.). Theor Appl Genet 1994, 89:365-371.

3. Wang M, Xia G, Peng Z: High UV-tolerance with introgression hybrid formation of Bupleurum scorzonerifolium Willd. Plant Sci 2005, 168:593-600

4. Zhou S, Brown DC: High efficiency plant production of North American ginseng via somatic embryogenesis from cotyledon explants. Plant Cell Rep 2006, 25:166-173.

5. Yamahara J, Konoshima T, Sawada T, Fujimura H: Biologically active principles of crude drugs: pharmacological actions of Swertia japonica extracts, swertiamarin and gentianine. Yakugaku Zasshi 1978, 98:1446-1451.

6. Kikuzaki H, Kawasaki Y, Kitamura S, Nakatani N: Secoiridoid glucosides from Swertia mileensis. Planta Med 1996, 62:35-38.
7. Brahmachari G, Mondal S, Gangopadhyay A, Gorai D, Mukhopadhyay B, Saha S, Brahmachari AK: Swertia (Gentianaceae): chemical and pharmacological aspects. Chem Biodivers 2004, 1:1627-1651.

8. Dewick PM: Medicinal Natural Products: A Biosynthetic Approach Chichester UK, John Wiley and Sons Pressi, 2002.

9. Oudin A, Courtois M, Rideau M, Clastre M: The iridoid pathway in Catharanthus roseus alkaloid biosynthesis. Phytochem Rev 2007, 6:259-276.

10. Mansuy D: The great diversity of reactions catalyzed by cytochrome P450. Comp Biochem Physiol Part C 1998, 121:5-14.

11. Werck-Reichhart D, Feyereisen R: Cytochromes P450: a success story. Genome Biol 2000, 1, REVIEWS3003.

12. Kahn R, Durst F: Function and evolution of plant cytochrome P450. Recent Adv Phytochem 2000, 34:151-189.

13. Collu G, Unver N, Peltenburg-Looman AM, van der Heijden R, Verpoorte $R$ Memelink J: Geraniol 10-hydroxylase, a cytochrome P450 enzyme involved in terpenoid indole alkaloid biosynthesis. FEBS Lett 2001, 508:215-220.

14. Wang JF, Liu YL, Cai YF, Zhang FF, Xia GM, Xiang FN: Cloning and functional analysis of geraniol 10-hydroxylase, a cytochrome P450 from Swertia mussotii Franch. Biosci Biotechnol Biochem 2010, 74:100175-1-8.

15. Chen $Y$, Tan LL, Cai X, Hu ZH: Advances on the studies of chemical constituents of Bupleurum L. Chinese Wild Plant Resources 2006, 2:8-11.

16. Xia GM, Li ZY, Chen HM: Plant regeneration from protoplast of Bupleurum scorzonerifolium. Plant Cell Reports 1992, 11:155-158.

17. Kisaka H, Kameya T: Production of somatic hybrids between Daucus carota and Nicotiana tabacum. Theol Appl Genet 1994, 88:75-80.

18. Kisaka H, Kisaka M, Kanno A, Kameya T: Intergeneric somatic hybridization of rice (Oryza sativa L.) and barley (Hordeum vulgare L.) by protoplast fusion. Plant Cell Reports 1998, 17:362-367.

19. Vlahova M, Hinnisdaels S, Frulleux F: UV irradiation as a tool for obtaining asymmetric somatic hybrids between Nicotiana plumbaginifolia and Lycopersicon esculentum. Theor Appl Genet 1997, 94:184-191.

20. Xiang FN, Xia GM, Chen HM: Effect of UV dosage on somatic hybridization between common wheat (Triticum aestivum L.) and Avena sativa L. Plant Sci 2003, 164:697-707.

21. Hall RD, Rouwendal GJA, Krens FA: Asymmetrc somatic cell hybridization in plants: The early effects of (sub) lethal doses of UV gamma radiation on the cell physiology and DNA intergrity of culture sugarbeet (Beta vulgaris L.) protoplasts. Mol Gen Genet 1992، 234:234-314.

22. Forsberg J, Dixelius C, Lagercrantz U, Glimelius K: UV dose dependent DNA elimination in asymmetric somatic hybrids between Brassica napus and Arabidopsis thaliana. Plant Sci 1998, 131:65-76

23. Xiang F, Xia G, Zhi D, Wang J, Nie H, Chen H: Regeneration of somatic hybrids in relation to the nuclear and cytoplasmic genomes of wheat and Setaria italica. Genome 2004, 47:680-8.

24. Escalante A, Imanishi S, Hossain M, Ohmido N, Fukui K: RFLP analysis and genomic in situ hybridization (GISH) in somatic hybrids and their progeny between Lycopersicon esculentum and Solanum lycopersicoides. Theor Appl Genet 1998, 96:719-726.

25. Li Y, Sink C: Cell type determines plastid transmission in tomato intergeneric somatic hybrids. Curr Genet 1992, 22:167-171.

26. Cardi T, Bastia T, Monti L, Earle ED: Organelle DNA and male fertility variation in Solanum sp., and interspecific somatic hybrids. Theor Appl Genet 1999, 99:819-828.

27. $\mathrm{Xu} C \mathrm{CH}$, Xia GM, Zhi DY, Xiang FN, Chen HM: Integration of maize nuclear and mitochondrial DNA into the wheat genome through somatic hybridization. Plant Sci 2003, 165:1001-1008.

28. Cai Y, Xiang F, Zhi D, Liu H, Xia G: Genotyping of somatic hybrids between Festuca arundinacea Schreb. and Triticum aestivum L. Plant Cell Rep 2007, 26:1809-1819.

29. Han L, Zhou CN, Shi J, Zhi DY, Xia GM: Ginsenoside Rb1 in asymmetric somatic hybrid calli of Daucus carota with Panax quinquefolius. Plant Cell Rep 2009, 28:627-638.

30. Murashige T, Skoog F: A revised medium for rapid growth and bioassays with tobacco tissue cultures. Physiol Plant 1962, 15:473-497.

31. Xiang FN, Li JM, Ma JX, Wu XM: Tissue culture of calli of Swertia musstii Franch. Chinese Traditional and Herbal Drugs 1996, 27:492-495.

32. Xia GM, Chen HM: Plant regeneration from intergeneric somatic hybridization between Triticum aestivum and Leymus chinensis. Plant Sci 1996, 120:197-203 
33. Hu NS, Wan XG: Application of isozyme technique. Changsha Hunan, Hunan Science and Technology Press; 1985, In Chinese.

34. Doyle JJ, Doyle Jl: Isolation of plant DNA from fresh tissue. Focus 1990, 12:13-15.

35. Xia GM, Li ZY, Wang SL, Xiang FN, Liu JY, Chen PD, Liu DJ: Asymmetric somatic hybridization between haploid wheat and UV irradiated Haynaldia villosa. Plant Sci 1998, 37:217-223.

36. Liu YL, Cai YF, Zhao ZJ, Wang JF, Li J, Xin W, Xia GM, Xiang FN: Cloning and functional analysis of a $\beta$-amyrin synthase gene associated with oleanolic acid biosynthesis in Gentiana straminea. Biol Pharm Bul 2009, 32:818-824.

doi:10.1186/1471-2229-11-71

Cite this article as: Wang et al:. Introgression of Swertia mussotii gene into Bupleurum scorzonerifolium via somatic hybridization. BMC Plant Biology 2011 11:71.

\section{Submit your next manuscript to BioMed Central} and take full advantage of:

- Convenient online submission

- Thorough peer review

- No space constraints or color figure charges

- Immediate publication on acceptance

- Inclusion in PubMed, CAS, Scopus and Google Scholar

- Research which is freely available for redistribution

Submit your manuscript at www.biomedcentral.com/submit 